\title{
ESOPHAGEAL MOTILITY IN TROUBLESOME BELCHING
}

\author{
Ana Cristina Viana da SILVA, Lilian Rose Otoboni APRILE and \\ Roberto Oliveira DANTAS
}

\begin{abstract}
Context - Supragastric belches are the main determinants of troublesome belching symptoms. In supragastric belches, air is rapidly brought into the esophagus and is immediately followed by a rapid expulsion before it has reached the stomach. Objective - To evaluate the esophageal contraction and transit after wet swallows in patients with troublesome belching. Methods - Esophageal contraction and transit were evaluated in 16 patients with troublesome belching and 15 controls. They were measured at 5, 10, 15, and 20 $\mathrm{cm}$ from the lower esophageal sphincter (LES) by a solid state manometric and impedance catheter. Each subject swallowed five $5 \mathrm{~mL}$ boluses of saline. Results - The amplitude, duration and area under the curve of contractions were similar in patients with troublesome belching and control subjects. The total esophageal bolus transit time was 6.2 (1.8) s in patients with troublesome belching and $6.1(2.3) \mathrm{s}$ in controls $(P=0.55)$. The bolus presence time was longer in controls than in patients at $5 \mathrm{~cm}$ from the LES [controls: $6.0(1.1) \mathrm{s}$, patients: $4.9(1.2) \mathrm{s}, P=0.04]$, without differences at 10,15 and $20 \mathrm{~cm}$ from the LES. The bolus head advanced time was longer in patients than controls from $20 \mathrm{~cm}$ to $15 \mathrm{~cm}$ [controls: $0.1(0.1) \mathrm{s}$, patients: $0.7(0.8) \mathrm{s}, P=0.01]$ and from $15 \mathrm{~cm}$ to $10 \mathrm{~cm}$ [controls: $0.3(0.1)$ s, patients: $1.6(2.6) \mathrm{s}, P=0.01]$ of the LES, without difference from $10 \mathrm{~cm}$ to $5 \mathrm{~cm}$ [controls: $0.7(0.3) \mathrm{s}$, patients: $1.0(1.1) \mathrm{s}$, $P=0.37]$. There was no difference in segment transit time. Conclusion - There was no difference in esophageal contractions between patients with troublesome belching and controls. The swallowed bolus went slower into the proximal and middle esophageal body in patients than in control, but cross the distal esophageal body faster in patients than in controls.
\end{abstract}

HEADINGS - Eructation. Esophageal motility disorders. Manometry. Electric impedance.

\section{INTRODUCTION}

In normal situations, gas enters the esophagus and goes to the stomach with each swallow. A possible release of this gas can be by belches ${ }^{(2)}$. Gastric belching is a physiological mechanism that enables the venting of gas from the stomach to the esophagus and is associated with transient lower esophageal sphincter relaxation ${ }^{(10)}$. It is not usual that this situation causes troublesome belching symptoms.

Some patients complain that they have excessive belching which causes discomfort and impairs their quality of life. Supragastric belches are the main determinants of troublesome belching symptoms ${ }^{(10)}$. In a supragastric belch, air is rapidly brought into the esophagus and is immediately followed by a rapid expulsion, before it has reached the $\operatorname{stomach}^{(9,10)}$. There is no transient lower esophageal sphincter relaxation ${ }^{(2)}$, but frequently in patients with severe complaints, the supragastric belch coincides with liquid gastroesophageal reflux ${ }^{(10)}$.

Described during supragastric belches are movements and alterations of the diaphragm, esophagogastric transition, pharyngoesophageal transition, esophageal and gastric pressures ${ }^{(9)}$. The consequence of the frequent flow of air into and rapidly out of the esophageal body on esophageal contraction and transit after wet swallows is not clear.

In recent years, belching as a symptom has received increased attention $(1,3,4,7,8,9,10)$. The objective of this study was to evaluate the esophageal contraction and transit after wet swallows in patients with troublesome belching. The hypothesis was that patients with troublesome belching have alterations of esophageal contractions and bolus transit.

\section{METHODS}

Esophageal contractions and transit were evaluated in 16 patients with troublesome belching, and 15 controls. The investigation was approved by the Human Research Committee of the University Hospital of Ribeirão Preto, SP, Brazil. All volunteers gave written informed consent to participate in the investigation.

The patients with troublesome belching included 6 men and 10 women aged 25-57 years (mean $46.2 \pm$ 8.2 years). They complained of excessive belching at least 3 times during the day, more than 3 times a week, 
for more than 6 months, causing problems at work and impairment of their familial and social life. Eleven patients had other esophageal and gastric symptoms, as heartburn and gastric pain, three had heartburn and depression and two did not have other symptom. They were asked questions before inclusion in the study as to terms of frequency, importance of the belches and previous treatment. The diagnosis takes the Roma III criteria ${ }^{(15,16)}$ into consideration. Patients did not have relief from symptoms with proton pump inhibitors, procinetics or antidepressives. The control group had six men and nine women, ages $25-58$ years (mean $46.2 \pm 7.8$ years). They did not have troublesome belches, heartburn or any complain in the digestive and respiratory tracts. Subjects of both groups did not have dysphagia. Controls and patients were recruited by advertisement from within our institution.

The esophageal contractions and transit were measured with a catheter of the Sandhill Scientific Manometry System (Highlands Ranch, CO, USA) that incorporates five pressure (two circumferential and three unidirectional) and four impedance-measuring segments. The solid state pressure transducers were placed $5 \mathrm{~cm}$ apart, and the impedance-measuring segment consisted of pairs of metal rings placed $2 \mathrm{~cm}$ apart, centered at the pressure transducers, thus straddling the four proximal pressure transducers. The signal from the catheter was transferred to an amplifying and digitalizing interface (Sensor PAC-Z, Sandhill Scientific Inc), recorded and stored using the dedicated software Insight Acquisition (Sandhill Scientific Inc) and Bio-View Analysis (Sandhill Scientific Inc). The amplitude, duration and area under the curve (AUC) of the contractions were analyzed on the manometric tracings and the total bolus transit time (TBTT), bolus head advance time (BHAT), bolus presence time (BPT) and segment transit time (STT) were analyzed on the impedance tracings, as previously described ${ }^{(17)}$.

The volunteers and patients were studied while sitting after 12 hours of fasting. The catheter was introduced through the nose until the distal circumferential pressure sensor registered the lower esophageal sphincter (LES) pressure. The other sensors registered the pressures at $5,10,15$, and $20 \mathrm{~cm}$ from the LES. The impedance values were registered at 5, 10, 15, and $20 \mathrm{~cm}$ from the LES. After 5 minutes of stabilization from recording, the presence of gastric belches, supragastric belches and air swallows were recorded for 20 minutes. After that each volunteer swallowed five $5 \mathrm{~mL}$ boluses of saline.

The statistical analysis was done by the Center of Quantitative Analysis of the Medical School of Ribeirão Preto USP (CEMEQ) using a linear model with mixed effects ${ }^{(13)}$. The model was adjusted using the Proc Mixed feature of the SAS software package version $9^{(11)}$. The results are reported as mean and standard deviation (SD), unless otherwise stated. The differences were considered significant when $P<0.05$ in a two-tailed statistical analysis.

\section{RESULTS}

Seen among the subjects of the control group during the base 20 minutes of registration were 2 to 5 episodes of gastric belches, no episodes of supragastric belches and 0 to 5 episodes of air swallow. The patients had 0 to 5 gastric belches, 1 to 11 supragastric belches and 0 to 35 episodes of air swallow.

The amplitude, duration and AUC of contractions were similar in patients with troublesome belching and control subjects (Table 1). In both groups, more than $90 \%$ of the contractions were peristaltic.

The total esophageal bolus transit time was $6.2(1.8) \mathrm{s}$ in patients with troublesome belching and 6.1 (2.3) $\mathrm{s}$ in controls $(P=0.55)$. The bolus presence time was longer in controls than in patients at $5 \mathrm{~cm}$ from the LES [controls: $6.0(1.1) \mathrm{s}$, patients: $4.9(1.2) \mathrm{s}, P=0.04]$, without differences at 10,15 and $20 \mathrm{~cm}$ from the LES (Table 2).

TABLE 1. Amplitude, duration and area under the curve (AUC) of esophageal contractions measured at 20,15, 10 and $5 \mathrm{~cm}$ from the lower esophageal sphincter in patients with troublesome belching $(n=16)$ and controls $(n=15)$. Mean $(S D)$

\begin{tabular}{cccccccccc}
\hline \multirow{2}{*}{$(\mathrm{cm})$} & \multicolumn{3}{c}{ Amplitude $(\mathrm{mm} \mathrm{Hg})$} & \multicolumn{3}{c}{ Duration (s) } & \multicolumn{3}{c}{ AUC (mm Hg x s) } \\
\cline { 2 - 9 } & Controls & Belching & $\boldsymbol{P}$ & Controls & Belching & $\boldsymbol{P}$ & Controls & Belching & $\boldsymbol{P}$ \\
\hline 20 & $74.2(41.3)$ & $66.8(55.1)$ & 0.40 & $1.6(0.4)$ & $1.5(1.1)$ & 0.70 & $88.5(46.9)$ & $61.1(41.1)$ & 0.10 \\
15 & $50.2(26.6)$ & $30.7(15.8)$ & 0.10 & $2.3(0.9)$ & $2.4(1.2)$ & 1.00 & $92.3(65.8)$ & $56.9(38.8)$ & 0.10 \\
10 & $72.1(37.8)$ & $57.6(35.0)$ & 0.30 & $2.7(1.0)$ & $2.7(1.1)$ & 0.90 & $147.6(88.5)$ & $109.2(63.1)$ & 0.50 \\
5 & $115.6(35.5)$ & $101.3(63.3)$ & 0.30 & $3.0(0.7)$ & $3.2(1.4)$ & 0.60 & $221.1(86.0)$ & $213.4(193.0)$ & 0.40 \\
\hline
\end{tabular}

TABLE 2. Bolus presence time (BPT), in seconds, measured at 20,15, 10 and $5 \mathrm{~cm}$ from the lower esophageal sphincter in patients with troublesome belching $(\mathrm{n}=16)$ and controls $(\mathrm{n}=15)$. Mean (SD)

\begin{tabular}{cccc}
\hline$(\mathrm{cm})$ & Controls & Belching & P \\
\hline 20 & $2.7(1.8)$ & $2.5(2.0)$ & 0.83 \\
15 & $3.7(1.5)$ & $3.2(1.4)$ & 0.39 \\
10 & $3.9(1.1)$ & $3.3(1.5)$ & 0.31 \\
5 & $6.0(1.1)$ & $4.9(1.2)$ & 0.04 \\
\hline
\end{tabular}


The bolus head advanced time was longer in patients than controls from $20 \mathrm{~cm}$ to $15 \mathrm{~cm}$ [controls: $0.1(0.1) \mathrm{s}$, patients: $0.7(0.8) \mathrm{s}, P=0.01]$ and from $15 \mathrm{~cm}$ to $10 \mathrm{~cm}$ [controls: $0.3(0.1)$ s, patients: $1.6(2.6) \mathrm{s}, P=0.01]$ of the esophageal body, without difference from $10 \mathrm{~cm}$ to $5 \mathrm{~cm}$ [controls: $0.7(0.3)$ s, patients: $1.0(1.1) \mathrm{s}, P=0.37]$. There was no difference in segment transit time (Table 3 ).

TABLE 3. Bolus head advanced time (BHAT) and segment transit time (STT), in seconds, measured from $20 \mathrm{~cm}$ to $15 \mathrm{~cm}$, from $15 \mathrm{~cm}$ to $10 \mathrm{~cm}$ and from $10 \mathrm{~cm}$ to $5 \mathrm{~cm}$ from the lower esophageal sphincter in patients with troublesome belching $(n=16)$ and controls $(n=15)$. Mean (SD)

\begin{tabular}{lccccccc}
\hline & \multicolumn{3}{c}{ BHAT } & & \multicolumn{3}{c}{ STT } \\
$(\mathrm{cm})$ & Controls & Belching & $\boldsymbol{P}$ & Controls & Belching & $\boldsymbol{P}$ \\
\hline $20 \rightarrow 15$ & $0.1(0.1)$ & $0.7(0.8)$ & 0.01 & $3.8(1.5)$ & $3.7(1.7)$ & 0.90 \\
$15 \rightarrow 10$ & $0.3(0.1)$ & $1.6(2.6)$ & 0.01 & $4.2(1.6)$ & $3.8(1.5)$ & 0.46 \\
$10 \rightarrow 5$ & $0.7(0.3)$ & $1.0(1.1)$ & 0.37 & $6.4(1.1)$ & $5.6(1.6)$ & 0.13 \\
\hline
\end{tabular}

\section{DISCUSSION}

Differences were not found in esophageal contractions between patients who complained of troublesome belching and control subjects. An increase during transit was observed of the bolus head advanced time in proximal and middle esophageal body and a decrease in bolus presence time in the distal esophageal body in patients with troublesome belching, resulting in a total esophageal bolus transit time similar to that seen in control subjects.

Belching can only be considered a disorder when it becomes troublesome. In typical cases, no investigation is required. A positive diagnosis is based on a careful history and observation of air swallowing ${ }^{(16)}$.

Subconcious air swallowing during eating and drinking is a normal physiological event and so is venting during transient relaxation of the lower esophageal sphincter ${ }^{(15)}$, a situation that does not cause symptoms. Some patients with gastroesophageal reflux disease have more swallows of air at meal time and also have more reflux episodes that contain gas, a situation that increases the possibility of no response to treatment with proton pump inhibitors ${ }^{(1)}$.

Supragastric belching is not associated with lower esophageal sphincter relaxation ${ }^{(2)}$, and is seen in patients with troublesome belching but not in asymptomatic subjects. The sequence of events that characterized the supragastric belches are movement of the diaphragm in an aboral direction and increased esophagogastric junction pressure, decrease in esophageal pressure, upper esophageal sphincter relaxation, antegrade airflow into the esophagus, increase in esophageal and gastric pressure leading to expulsion of air out of the esophagus in retrograde direction ${ }^{(9)}$. This sequence of events causes troublesome belching, discomfort and social disability.

Chronic air swallowing behavior might explain the longer transit time in proximal esophagus and the faster transit in distal esophagus, but although the difference with the control group was significant, the transit alteration is not likely to have clinical importance. The slow proximal esophageal liquid flow during swallowing may be a consequence of the pressure inside the esophagus, which may not facilitate the liquid flow, opposite to the decrease in esophageal pressure during the rapid air flow into the esophagus. The decrease of esophageal pressure immediately after swallow is physiologic, consequence of a wave of inhibition that precedes primary peristaltic contractions ${ }^{(14)}$. It is possible that in these patients the esophageal body relaxation seen in the situation of wet swallow is different from the relaxation in situation of air swallow, a hypothesis that needs further investigations. It is likely that the observed transit alterations are consequence of the frequent supragastric belches. The symptoms of the patients should be caused by the belches and not by the esophageal transit alterations.

Our evaluation was performed only with liquid bolus. With solid bolus, it is possible to find different results. Swallowing a solid bolus causes a different esophageal motility response when compared with a liquid bolus. With solid bolus the contraction amplitude increase and the segmental transit time is longer than with liquid bolus ${ }^{(5,12)}$.

The knowledge that troublesome belching does not cause esophageal contraction alterations and causes only minor changes in esophageal transit has implications in treatment. The patients with troublesome belching are referred to therapies such as biofeedback, diaphragmatic breathing and speech therapy, with variable results ${ }^{(4,7,8)}$. Speech therapy is a new and promising therapy that focus on explanation and on creating awareness of the belching mechanism. It should be performed by a well-informed speech pathologist and consist of an explanation about the behavior mechanism that cause the injection or sucking of air, consequence of increasing the pharyngeal pressure or reducing intrathoracic reduced pressure respectively, and by conventional breathing and vocal exercises ${ }^{(7)}$. Patients with associated gastroesophageal reflux disease should receive treatment for this disease, such as lifestyle modification and proton pump inhibitors. However, they do not need treatment for esophageal motility disorder in addition to esophageal motility alterations not being the cause of the disease.

Five swallows of saline were performed in the evaluation of esophageal motility. Ten or more swallows of liquid bolus are needed when the esophageal manometry is performed with the intention to make diagnosis of esophageal motility disorder. However, for the evaluation of amplitude and duration of contractions, five swallows has been demonstrated to be enough ${ }^{(6)}$.

In conclusion, there was no difference in esophageal contractions between patients with troublesome belching and controls. The swallowed bolus went slower into the proximal and middle esophageal body in patients than in control, but crossed the distal esophageal body faster in patients than in controls. 
Silva ACV, Aprile LRO, Dantas RO. Motilidade do esôfago de pacientes com eructação supragástrica. Arq Gastroenterol. 2013,50(2):107-10.

RESUMO - Contexto - Na eructação esofágica o ar é rapidamente trazido para o esôfago, fato imediatamente seguido pela rápida expulsão, antes de ter atingido o estômago. Objetivo - Avaliar a contração e o trânsito pelo esôfago após deglutições líquidas em pacientes com eructações excessivas. Métodos - Contração do esôfago e o trânsito foram avaliados em 16 pacientes com eructações excessivas e 15 controles. Elas foram medidas a 5 , 10 , 15 e $20 \mathrm{~cm}$ do esfíncter inferior do esôfago (EIE) por um cateter em estado sólido de manometria e impedância. Cada indivíduo deglutiu cinco vezes 5 $\mathrm{mL}$ de salina. Resultados - A amplitude, duração e área sob a curva das contrações foram similares em pacientes com eructação e controles. O tempo total de trânsito esofágico foi de $6,2(1,8) \mathrm{s}$ em pacientes com eructação e $6,1(2,3) \mathrm{s} \mathrm{em} \mathrm{controles}(P=0,55)$. O tempo de presença de bolus foi mais longo nos controles do que nos pacientes a $5 \mathrm{~cm}$ do EIE [controles: $6.0(1.1) \mathrm{s}$, pacientes: $4.9(1.2) \mathrm{s}, P=0,04$ ], sem diferenças a 10,15 e $20 \mathrm{~cm}$ do EIE. O tempo de avanço da cabeça bolo foi mais longo em pacientes do que nos controles, de $20 \mathrm{~cm}$ a $15 \mathrm{~cm}$ [controles: $0,1(0,1) \mathrm{s}$, pacientes: $0,7(0,8) \mathrm{s}$, $P=0,01$ ] e de $15 \mathrm{~cm}$ a $10 \mathrm{~cm}$ [controles: $0,3(0,1) \mathrm{s}$, pacientes: $1.6(2.6) \mathrm{s}, P=0,01$ ] do corpo esofágico, sem diferença de $10 \mathrm{~cm}$ a $5 \mathrm{~cm}$ [controles: $0,7(0,3)$ s, de pacientes: $1.0(1.1) \mathrm{s}, P=0,37]$. Não houve diferença no tempo de trânsito segmentar. Conclusão - Não houve diferença nas contrações do esôfago entre pacientes com eructação excessiva e controles. O bolo líquido deglutido teve propagação mais lenta nas partes proximal e média do esôfago em pacientes do que nos controles, mas ao atravessar o corpo distal do esôfago foi mais rápido em pacientes do que nos controles.

DESCRITORES - Eructação. Transtornos da motilidade esofágica. Manometria. Impedância elétrica.

\section{REFERENCES}

1. Bravi I, Woodland P, Gil RS, Al-Zinaty M, Bredenoord AJ, Sifrim D. Increased prandial air swallowing and postprandial gas-liquid reflux among patients refractory to proton pump inhibitor therapy. Clin Gastroenterol Hepatol. 2013. doi: 10.1016/j.cgh.2012.12.041.

2. Bredenoord AJ, Weusten BL, Sifrim D, Timmer R, Smout AJ. Aerophagia, gastric, and supragastric belching: a study using intraluminal electrical impedance monitoring. Gut. 2004;53:1561-5.

3. Bredenoord AJ. Excessive belching and aerophagia: two different disorders. Dis Esophagus. 2010;23:347-52.

4. Bredenoord AJ. Management of belching, hiccups, and aeropagia. Clin Gastroenterol Hepatol. 2013;11:6-12.

5. Dalmazo J, Aprile LRO, Dantas RO. Esophageal contractions, bolus transit and perception of transit after swallows of liquid and solid boluses in normal subjects. Arq Gastroenterol. 2012;49:250-4.

6. Dantas RO. Effect of successive swallows on esophageal motility of normal volunteers, patients with Chagas' disease and patients with idiopathic achalasia. Neurogastroenterol Motil. 2003;15:57-62.

7. Hemmink GJ, Ten Cate L, Bredenoord AJ, Timmer R, Weusten BL Smout AJ. Speech terapy in patients with excessive belching - a pilot study. Neurogastroenterol Motil. 2010;22:24-e3.

8. Katzka DA. Simple office-based behavioral approach to patients with chronic belching. Dis Esophagus. 2012. doi: 10.1111/dote.12006.
9. Kessing BF, Bredenoord AJ, Smout AJPM. Mechanisms of gastric and supragastric belching: a study using concurrent high-resolution manometry and impedance monitoring. Neurogastroenterol Motil. 2012;24:e573-9.

10. Kessing BF, Bredenoord AJ, Velosa M, Smout AJPM. Supragastric belches are the main determinants of troublesome belching symptoms in patients with gastro-oesophageal reflux disease. Aliment Pharmacol Ther. 2012;35:1073-9.

11. Little RC, Milliken GA, Stroup WW, Wolfinger RD, Schabenberger O. SAS system for mixed models. Cary, NC: SAS Institute, 1996.

12. Pouderoux P, Shi G, Tatum RP, Kahrilas RJ. Esophageal solid bolus transit: studies using concurrent videofluoroscopy and manometry. Am J Gastroenterol. 1999; $94: 1457-63$.

13. Schall R. Estimation in generalized linear models with random effects. Biometrika 1991;78:719-27.

14. Sifrim D, Janssens J, Vantrappen G. A wave of inhibition precedes primary peristaltic contractions in human esophagus. Gastroenterology. 1992;103:376-82.

15. Tack J, Talley NJ, Camillieri M, Holtmann G, Hu P, Malagelada JR, Stanghellini V. Functional gastroduodenal disorders. Gastroenterology. 2006;130:1466-79.

16. Tack J, Talley NJ. Transtornos gastroduodenais. Arq Gastroenterol. 2012;49(Supl):21-27.

17. Tutuian R, Vela MF, Shay SS, Castell DO. Multichannel intraluminal impedance in esophageal function testing and gastroesophageal reflux monitoring. J Clin Gastroenterol. 2003;37:206-15. 